\title{
Violência rural e bandoleirismo na Patagônia
}

\author{
Gabriel Rafart
}

...o bandoleiro é, com frequência, destruidor e selvagem, até um ponto
em que ultrapassa os limites impostos por seu mito...
Eric Hobsbawm, Bandidos, 1976.

\section{Introdução: violência, lei e bandoleirismo ${ }^{1}$}

A Patagônia argentina e chilena conta com relatos variados sobre formas de violência próprias de um mundo rural em situação de fronteira, entre elas um bandoleirismo muito difundido. De ambos os lados da Cordilheira dos Andes, nesse extremo sul do continente, houve bandidos "lendários". Outros relatos referiam-se a figuras mesquinhas e criminosas. Havia aqueles que provinham dos setores subalternos e outros que praticavam o banditismo como "negócio", para ampliar suas fortunas. Não obstante, a maioria tinha essa prática como mecanismo de sobrevivência e muitas de suas vítimas pertenciam aos setores imersos na pobreza.

Qual desses dois tipos de "bandidos” predominou nesses territórios longínquos? O bandido social ou o criminoso? Os dois faziam parte, sem dúvida, da vida patagônia. É certo que, a exemplo de outras realidades, o bandido era o resultado de uma construção discursiva própria de terrenos em conflito. Como tal, ela foi uma fórmula de profundo impacto cultural que ia além da tentativa de distinguir o legal do ilegal. Ela procurava, também, identificar aqueles que se haviam inclinado à desordem em uma sociedade que carecia de contornos definidos, embora se buscasse cristalizar um horizonte de respeito à propriedade privada e ao império da Lei do Estado. Sem dúvida, a identificação do bandido reunia condições para produzir poderosas representações.

Essa mesma identidade foi parte de uma batalha cultural de difícil resolução, na medida em que se tentava transformar esse discurso em prática e realidade legitimadora de uma ordem estatal em expansão. Por essa razão, muitos atores sociais que denunciavam essas formas de violência evitavam atribuir à vida e à obra dos bandoleiros da região alguma conotação romântica. Com efeito, as opiniōes dos agentes culturais do progresso, em seus jornais, suas memórias, seus relatórios e nos relatos de viajantes, careciam de qualquer imagem condescendente. Elas falavam de criminosos sem vestígios de princípios morais. Muitas dessas narrativas estavam destinadas a outros públicos que nunca haviam pisado o território patagônio. Faziam parte da construção de uma opinião pública para o mundo citadino de Buenos Aires, mas seu destino não era apenas a elite da capital. Ela era projetada também para uma cultura de massas consumidora de todos os tipos de relatos, entre os quais aqueles que conferiam um valor positivo à ação justiceira. Para esses setores, foi montado um discurso condenatório e de extermínio do bandoleiro, destinado a legitimar a função repressora do aparelho estatal.

No último terço do século XIX, a elite dirigente argentina valeu-se da fórmula tripartite que reunia Paz, Legislação e Administração para impor a ordem nas novas realidades territoriais e institucionais conquistadas com a ocupação do espaço patagônio-pampeano. Esses dirigentes entendiam que, uma vez expulso o índio e ocupado o espaço por homens imbuídos da ideia de civilização e progresso, estariam dadas as condições para que se constituísse uma sociedade de novo tipo. Essa utopia do progresso e da ordem outorgava um lugar central às estruturas administrativas e ao cumprimento da lei. Foi sob essa fórmula que se elaborou o discurso do final do século XIX. No entanto, nem tudo isso foi possível, visto que esse programa careceu, até bem adiantado o século $\mathrm{XX}$, de uma estrutura burocrática forte. A escassa provisão de recursos materiais e humanos, a corrupção que grassava entre os funcionários, as dificuldades em impor uma cultura da Lei e outros tantos males jogaram por terra o projeto de uma ordem estatal harmoniosa e pacífica. A violência foi inevitável. 
A débil armadura institucional que o Estado nacional colocou em prática na Patagônia não logrou conduzir uma verdadeira guerra de movimentos para impor-se sobre as tropas "irregulares" que conformavam parte do mundo do delito. Em consequência, o que se impôs foi uma guerra de posiçóes. Houve homens e mulheres em condiçóes de erigir verdadeiras trincheiras defensivas. Eles foram os protagonistas da história social da sociedade civil patagônia. Essa mesma sociedade viu-se, de um momento para outro, em meio a regras que consideravam próprias, através das quais se dava refúgio ao crime mais doloroso, o bandoleirismo. Ali, tanto se recrutavam os homens, como se obtinham os meios que permitiram o surgimento de tantos bandidos e grupos de bandoleiros.

Para alcançar o propósito de construir uma ordem sob o império da lei, o aparato burocrático insistiu em impor um pacto social que discriminava as condutas ilegais das outras que não se encaixavam nesse molde. Esse processo gerou posiçôes de poder que foram "intercambiadas e distribuídas", acompanhando de perto os êxitos e as derrotas na luta contra o bandoleirismo e outras formas de violência. Os postos de autoridade dependeram em grande parte do entrecruzamento de relações de força existentes na comunidade, as quais, por sua vez, dependiam do compromisso na luta contra esses crimes.

Impor a lei e o castigo fez parte de um processo repleto de dificuldades, especialmente quando o mundo criminoso se expressava através dos distintos rostos que o bandoleirismo expunha. Foram decisivos os atores reconhecidos como tais e o impacto de suas condutas sobre a construção da ordem tão desejada. A sociedade patagônia privilegiou a identificação do bandoleirismo em relação a outras formas de delinquência da época, sendo o crime dele resultante aquele que condensava as principais tensões de uma comunidade em formação. Foram, sobretudo, proprietários e funcionários, os promotores desse império da lei e foram eles também que designaram o mundo do bandido como o inimigo principal, ainda que a designação de bandido tivesse múltiplos significados.

Para a realidade patagônia de fins do XIX e do primeiro terço do século XX é correta a afirmação de Eric Hobsbawm de que o bandoleirismo, como fenômeno universal, é expressão de contextos em profundas mutações. Precisando esses termos, cabem, para a maior parte do amplo espaço do sul da Argentina, as reflexões que Paul J. Vanderwood fez para o México do Porfiriato. Ele observou que o banditismo floresce naqueles interstícios geopolíticos nos quais o controle e a influência do centro exercem pouco domínio e onde a influência judicial é mais débil. ${ }^{2}$

Nesses imensos espaços, principalmente na área das cordilheiras patagônias, o alcance social do banditismo esteve longe de carregar uma imagem condescendente, como "substituto do protesto social", configurando, antes, um tipo de relacionamento societário que procurava canalizar e viver seus conflitos como situações regulares. Essa regularização estabeleceu rituais que possibilitaram afirmar um sentido de obrigação e autoridade dentro das próprias comunidades em formação, e entre estas e os representantes do Estado. Com efeito, o banditismo cristalizou práticas e certo tipo de sociabilidade, assim como um horizonte cultural, no interior dos quais a dinâmica social julgou estar em condições de oferecer um modelo distinto de governo. Esse modelo expressou-se naqueles que tentaram se despojar de toda a rede de obrigaçôes para com as autoridades estatais e, consequentemente, mantiveram em suas mãos os instrumentos de coerção para exercer um modelo de castigo.

Houve duas maneiras de viver e pensar as relações sociais e de coordenação estatal. Por um lado, faziam-se presentes as instituições e os representantes da Lei do Estado. Por outro, a própria sociedade civil, com sua "lei primária" e seus homens armados. Como afirmam Maria Elba Argeri e Sandra Ghía, a "luta entre a sociedade e a forma embrionária do Estado territorial tornou-se uma batalha encarniçada, sobretudo devido às contradiçôes existentes em ambas as dimensões, demorando-se, assim, por longas décadas o processo de subordinação à forma estatal". ${ }^{3}$

No longo prazo, esse foi um processo que buscou um tipo de hegemonia cujo eixo principal foi a colocação em prática da regulação e da conciliação de conflitos, através da norma legal. Certamente, nos albores do século XX, a primazia da lei estava chegando a todos os rincôes do país, junto com o 
avanço do capitalismo. Naturalmente, o espaço patagônio, apesar de sua realidade periférica, também foi incluído neste cenário global, embora tal processo tenha demorado mais do que o esperado por seus promotores. Similar ao que ocorreu em outros cenários, a lei só pôde efetivar-se quando conseguiu ganhar, em primeiro lugar, o "coração" e as práticas dos homens da instituição policial e as duas instâncias encarregadas da administração da justiça. Em sua luta travada contra o bandoleirismo, houve espaço para colocar em jogo o alcance dessa cultura legal.

O sentido primário do exercício da justiça, digamos "por conta própria", foi um compromisso prático difícil de erradicar e avalizado, individual ou coletivamente, por importantes setores da sociedade. Em consequência, houve prolongados períodos de crise de autoridade. Essas crises eram causadas não apenas pelo desafio dos bandoleiros, mas também por muitas práticas cotidianas presentes nas comunidades indígenas subjugadas. A elas se somavam as variadas formas de resistência de camponeses e marginalizados e migrantes expulsos de uma ordem social e econômica promovida pelo pujante capitalismo agrário do centro-sul do Chile. Eles formavam os setores populares que tinham pouco ou nada a perder. A prática do bandoleirismo revelava, às vezes, uma forma de resistência; outras, de vingança frente a essa ordem injusta. Em contrapartida, outros setores, proprietários ou indivíduos em busca de maiores recursos, também fizeram uso desse peculiar exercício da justiça.

\section{Bandoleiros imaginados, bandidos reais}

No panteão de bandoleiros rurais patagônios destaca-se Ascencio Brunel, conhecido como o "demônio da Patagônia" ou "o bandoleiro fantasma”. Nascido no Uruguai, chegou à Patagônia argentina a partir de Punta Arenas. Nessa localidade chilena cometeu um homicídio por "problemas de mulher". Seu ingresso no mundo do crime repete certo padrão comum a outras figuras do bandoleirismo argentino, como Juan Bautista Vairoleto. ${ }^{4}$ Brunel atuou como bandoleiro no extremo sul do continente na última década do século XIX e na primeira do século XX. Sua trajetória ressalta os atributos do bandido romântico. Acusado de roubo de gado e também do homicídio de um fazendeiro, ele roubava tropas de equinos tanto em território chileno quanto argentino, como faziam membros das comunidades indígenas. Segundo uma das versóes, Brunel morreu nas mãos de um grupo indígena. Outras afirmam que ele viveu muitos anos longe da Patagônia.

Junto a Brunel soma-se uma figura feminina, Elena Greenhill, conhecida como a "bandoleira inglesa”. Ela mudou-se com a família da Inglaterra para a Patagônia chilena e, depois de casada, instalou-se no território de Neuquén e, posteriormente, no de Rio Negro. La Inglesa desenvolveu suas atividades durante os 15 primeiros anos do século XX. Segundo consta nos despachos judiciais, ingressou no mundo do comércio ilegal de gado através de seu marido chileno, Manuel de la Cruz Astete, assassinado em virtude de seus "negócios", o que acarretou problemas para Greenhill ser reconhecida como herdeira dos seus bens. Além da permanente hostilidade de certas autoridades judiciais e policiais, um novo casamento, com Martín Coria, acrescentou inimigos importantes à sua agitada vida. Elena Greenhill conseguiu montar fortes redes de solidariedade envolvendo astutos comerciantes dos dois lados da cordilheira, mas também granjeou a inimizade de funcionários e policiais que, por vingança e ofensas nunca esclarecidas, decidiram pôr fim à sua vida. Sua biografia revela a existência de uma complexa trama de negócios entre a comunidade britânica e seus descendentes nessa porção do território argentino. Por outro lado, a história de Greenhill assinala as marcas das cumplicidades e dos silêncios próprios dessas redes, quando não as traições dos funcionários da justiça. Por intermédio dessa mulher, fica-se também conhecendo o lado "social" do bandoleirismo, envolvendo comerciantes e proprietários de gado que mantinham negócios eventualmente lícitos e outros nem tanto. "A Inglesa” foi executada pelas balas de um comissário da polícia em Gan Gan, no território de Chubut.

O bando de Butch Cassidy e Sundance Kid também faz parte desse mundo de bandoleiros lendários. ${ }^{5}$ Os dois viveram apenas cinco anos na Patagônia. Dois assaltos realizados contra estabelecimentos 
bancários em pontos tão distantes como Rio Gallegos e Villa Mercedes conferiram aos norte-americanos a aura de bandidos de lenda. Também a perseguição promovida por detetives da agência Pinkerton e a busca infrutífera que os grupos volantes da polícia fronteiriça lhes moveram, fizeram-nos credores de uma fama incalculável para a época. Muitos anos depois de terem saído do território cordilheirano, as autoridades continuaram organizando destacamentos policiais para iniciarem novas perseguições, o que não era mais do que o produto do temor de que esses bandidos voltassem a aparecer. Esses temores subsistiram após a segunda década do século passado, mesmo depois da morte de Robert Evans e William Wilson, ambos ligados a Cassidy e a Kid, em Rio Pico, em meados de junho de 1911.

Além de Brunel, da Inglesa e da dupla Cassidy-Kid, houve outra figura que remete à disputa pelo bandoleirismo como parte do imaginário de homens dispostos a enfrentar a lei e que, além disso, desfrutava de fortes simpatias entre os membros de suas comunidades, e mesmo entre aqueles encarregados de colocar um ponto final em suas açôes delituosas. Nascido em 1912, Eugenio Ovando Patiño lançou-se à vida ilegal desde a mais tenra idade, tendo por território predileto Chubut e parte da meseta de Rio Negro. Capturado na década de 1930, foi condenado a uma pena prolongada. Entre seus perseguidores foi forjada, a seu respeito, a figura de um bandoleiro aventureiro e valoroso.

Sobre todos eles se construiu um mito, a ideia de um tipo de bandido excepcional, que perdurou para além do período em que muitos deles desenvolveram suas ações delituosas. Em compensação, houve outros criminosos que só resultaram em notícias para as páginas policiais, nas quais eram narrados seus crimes, ou informava-se de sua prisão ou morte. Estes - que, em sua maior parte, deram origem à ideia de um banditismo cruel, parte integrante de uma sociedade que vivia uma violência endêmica - faziam parte de um mundo criminoso "fora de controle". Foi o caso do bando comandado por Roberto Focter (Foster) Rojas, indivíduo sobre o qual pesava um conjunto de delitos. Em 1928, durante quase dois meses, uma parcela da população residente nas proximidades de San Carlos de Bariloche, em Rio Negro, e os moradores mais ao sul de Esquel, na província de Chubut, foram vítimas de uma onda de assaltos e assassinatos a mando de seu grupo. A partir desses fatos, Rojas recebeu a alcunha de "El Chacal da Lipela". ${ }^{6}$

Com base nesses dois tipos de bandidos - o imaginado e o real, com balas e homicídios -, elaborou-se um discurso similar ao do violento oeste norte-americano. Uma espécie de far west com bandidos temerários e policiais desafiados. A pena do cronista é precisa. A Patagônia é "o perigoso Far West das películas norte-americanas, com personagens impenetravelmente temerários e com o arsenal de pólvora homicida".

Já bem entrado o século XX, houve vozes que exageraram, falando de uma Patagônia violenta. Todas elas se encarregaram de apresentar um ator carregado de ressentimento e muito feroz. Projetou-se a imagem de um banditismo de raiz patagônia, selvagem e impiedoso. $\mathrm{O}$ bandoleirismo foi visto, então, como expressão palpável de uma extensa paisagem social, extremamente brutal e muito distante da civilização. Esse imaginário parecia não ter adquirido maior ressonância pela memória de um passado carregado de episódios de violência, pilhagem e morte - nem tampouco da cruenta campanha militar que pôs fim aos levantes dos trabalhadores das fazendas de Santa Cruz; o primeiro ocorrido em 1919 e o segundo, nessa mesma região, dois anos depois, e que enfrentou dura repressão - mas, sim, pelas aspiraçôes a favor de uma sociabilidade comprometida com as pautas da civilização progressista.

Surgia a construção de um tipo de bandoleiro especial de raiz local: o bandido patagônio. Sob esse rótulo, tentava-se estabelecer um ponto de referência sociocultural e espacial diferentes. Esse ponto de vista, dominante à época, foi expresso, entre outros, pelo advogado e funcionário judicial do território de Rio Negro, Oscar Fermín Lapalma, em sua trajetória pelo norte da Patagônia no começo dos anos trinta do século XX. A exemplo de outras penas influentes, Lapalma "elaborou" um tipo de bandoleiro adequado para algo mais do que o consumo dos setores dirigentes, da mesma maneira que representava um avanço na sua própria narrativa sobre a ordem civilizatória desejada. 
A comparação era pertinente com o tipo de registro cristalizado durante as décadas precedentes em certos folhetins da época sobre certos bandidos. Bandoleiros como Juan Moreira, o "Tigre de Quequén", Julio e Pedro Barrientos, Pastor Luna e Guillermo Hoyos, conhecido como "Formiga Negra", cabiam na lenda. Todos haviam atuado na área pampeana litorânea durante a segunda metade do século XIX. Segundo um relato crítico, a biografia de nenhum deles, contudo, assemelhava-se à do bandoleiro que assolava a região patagônia. Aqueles personagens pertenciam ao mundo dos "heróis pobres" de uma sociedade rural, dos tempos "federais" ligados a causas populares, daí sua ampla aceitação no interior desses setores. Sabendo que havia uma cultura imposta a partir da literatura gauchesca, Lapalma procurava colocar as coisas em seu lugar, dando sua contribuição à representação pública desses "heróis", homens astutos, matreros de leyenda.

Uma espécie de determinismo geográfico, próprio da época, conferia sentido à "história natural" do bandoleirismo territorial. Numa entrevista dada a um jornalista do então semanário Río Negro, Lapalma afirmava que:

A Patagônia, com suas imensas zonas desabitadas, sua enorme extensão repleta de acidentes topográficos, seus vastíssimos pampas inóspitos no centro, seus bosques da cordilheira, sua escassez de centros urbanos, sua população analfabeta, espalhada, e, em sua maioria, sem coesão familiar, tinha mesmo que produzir esta temível manifestação de criminalidade: o bandoleirismo. ${ }^{8}$

Nesse relato, o pampeano "astuto" era apresentado como um homem tranquilo e batalhador. Seus atos eram de valentia e audácia. Era um homem de honra que, inclusive, merecia um lugar destacado na história da formação da nacionalidade argentina. Era o criollo dos pampas. Diante dele, o bandoleiro patagônio foi um criminoso sem moral, um ser sem piedade, calculista, sem sentimentos, ao qual só restava ser perseguido e exterminado:

O matrero jamais se entregava à autoridade sem lutar até a morte, porque esse descendente criollo do cavaleiro andante era um gaúcho da velha cepa, "touro em seu rodeio e touro ainda mais valente em rodeio alheio". Já este bandido, criminoso e ladrão [o patagônio], mata seus perseguidores, quando pode disparar suas armas sem risco algum, mas se está em situação de equilíbrio ou de desvantagem, se entrega sem resistência, como ocorreu em Rio Negro com os Elmes, os Rojas Foster, os Román etc. ${ }^{9}$

Nenhum desses criminosos conseguiu uma identificação positiva, embora alguns destacassem seu espírito de aventura, arrojo e, em determinadas ocasiōes, certa valentia. Víctor Elmes, por exemplo, que havia sido um dos lugares-tenentes de Vairoleto, ${ }^{10}$ era tratado como um "elemento audaz, de uma temibilidade (sic) sem igual". Sua espetacular tentativa de fuga foi registrada pelas crônicas policiais. Capturado em 1932, nesse mesmo ano tentou evadir-se do presídio de Viedma. Após ter cumprido a pena, foi acusado de ter sido o responsável pela morte de um policial de Rio Negro. Em fins de outubro de 1937, novamente na prisão, tentou fugir quando regressava ao estabelecimento carcerário de General Roca, depois de realizar tarefas de utilidade pública, como era comum entre os presos. Conseguiu dominar dois carcereiros e em seguida apoderou-se do caminhão em que viajava. O fugitivo dirigiu até as proximidades do rio Negro. Na fuga, acabou caindo em um canal que o arrastou até o leito do rio. Poucos dias depois, depois de uma intensa busca, seu corpo foi retirado do rio. Tinha dois balaços. ${ }^{11}$

Pretendeu-se montar um mito negativo em relação aos bandoleiros patagônios, recorrendo ao falseamento de dados históricos. Com esse discurso negativo tentava-se estabelecer uma distância entre eles e esses matreros heróicos, cujos traços popularizados projetaram a imagem, durante sua época, de uma espécie de santos milagrosos. Nos anos vinte e trinta do século XX, havia um sólido imaginário social construído em torno de delinquentes protegidos, aos quais era atribuída a aura de homens santificados. Os criminólogos da época reconhecem esta presença. Emilio Catalán, na prestigiosa Revista de Criminología, descrevia esse fenômeno na figura do bandoleiro Andrés Bazán Frias, conhecido como "o Manco" ou "o Canhoto", que atuou, sobretudo, na província de Tucumán e que foi morto quando ten- 
tava escapar das forças policiais, escalando um muro, na capital provincial, em 13 de janeiro de $1923 .^{12}$ Mas Bazán Frias não foi o único bandoleiro a ser entronizado pela devoção popular. ${ }^{13}$

Esse discurso procurava impor uma espécie de "patriotismo da lei", ao qual se somava outro, de tom "patagônio", marcado pelo respeito à autoridade, pela laboriosidade de seus indivíduos e, acima de tudo, por um compromisso com a luta sem quartel contra os sujeitos de má índole, nascidos numa natureza hostil. Os bandidos da Patagônia estavam longe de fazer parte da nação e da sociedade dos homens do progresso. Deviam ser combatidos com o Código Penal, não só um catálogo de delitos e penas, mas, um instrumento de defesa social. Este era o conceito de um tempo que parecia ter parado no século XIX, pela necessidade de promulgar uma lei sobre o "estado perigoso", devendo a autoridade policial assumir um "critério nacional" para vigiar muito de perto "a enorme quantidade de vadios, dedicados à vagabundagem como único meio de vida". Os bandidos eram considerados como o resultado inevitável da massa de vencidos numa guerra de longa data entre a civilização e a barbárie. A"lei da defesa social" devia impor-se.

Segundo esses relatos, os bandidos patagônios eram sujeitos infames. Nada havia de emocionante nesses atores do delito, nem sequer naqueles que pudessem ter cometido atos de justiça distributiva ou que tivessem sido empurrados para o delito por necessidade, e outros por alguma afronta à honra. $\mathrm{O}$ mesmo se aplicava àqueles que enfrentavam uma pobreza crescente e que faziam suas vítimas entre os grandes proprietários e comerciantes.

\section{O bandido "estrangeiro", trabalhadores chilenos bandoleiros e o índio bandoleiro}

A Patagônia era um território extenso e de difícil trânsito. À escassez de população somava-se a presença de ocupantes precários ou de intrusos, quer fossem de origem mestiça, quer fossem indígenas. Ambos os traços caracterizavam um ambiente propício para o domínio de grupos de bandoleiros. Essa imagem era ainda mais reforçada se esses bandoleiros fossem, em sua maioria, de nacionalidade chilena e se se mostrassem pouco dispostos a abandonar os laços materiais, a cultura e as formas de sociabilidade com o país que os havia visto nascer. No mundo rural da Cordilheira e especialmente no de Neuquén, ${ }^{14}$ a presença chilena foi de maior peso do que no débil cenário urbano.

A elite local, em grande parte devido à sua chegada recente e à sua vontade em deixar clara sua condição de setor socialmente dominante, acreditava ver nesse caráter de fronteira - "chilenidade", vagabundagem, ociosidade, mestiçagem, indigenismo, ruralidade e pobreza extrema - os ingredientes propícios à proliferação do bandoleirismo. As autoridades locais também fizeram eco às opiniōes destacadas pela imprensa, que identificavam os chilenos como protagonistas quase exclusivos desses delitos. Em 1900, o governador do território de Neuquén, Lisandro Olmos, assim informava às autoridades centrais:

Tenho que anunciar que as notícias que os diários dessa Capital registram são desgraçadamente corretas. A depredação que hordas de foragidos chefiados por chilenos levam a cabo neste Território é o flagelo que marca o próximo término do verão.

Os salteadores em bando, armados de Winchester e Malincher bem municiadas, e com montaria ainda melhor, percorrem todas as estâncias próximas à cordilheira, onde fazem seus saques, assassinatos e roubos de fazendas e dinheiro, sem que a polícia possa dar caça aos mais fortes. ${ }^{15}$

No inverno de 1900, o diretor de outro jornal regional destacava o protagonismo do bandido "estrangeiro":

As nevadas dos dias anteriores foram como uma cortina no último ato das tragédias; baixa a cortina e o drama se encerra até a outra sessão. Terminou, por este ano, o bandoleirismo que ofereceu abundante material aos anais do crime: roubos, saques, assaltos, homicídios, tudo contribuiu para tornar mais interessante o argumento que indubitavelmente será melhor no próximo ano, pois a isso os chefôes dedicarão sua atividade incessante, durante o inverno, entre os bastidores da ultracordilheira. ${ }^{16}$ 
Transcorridos vários anos após a publicação daquela matéria, opiniões semelhantes continuaram sendo divulgadas. Uma década depois, o jornal La Nación, afirmava que se "os chilenos são qualificados de bandidos do sul é pela simples razão de que usam o solo da república vizinha para se colocarem a salvo, fazerem seus negócios com gado e prepararem suas novas incursões". ${ }^{17}$

Segundo a imprensa da época, a origem e a proliferação do banditismo eram explicadas pela imprecisão das fronteiras. Nessa geografia fronteiriça havia passagens regulares e inumeráveis trechos clandestinos por onde se podia circular praticamente durante a maior parte do ano. Eram, na realidade, fronteiras imaginadas, uma vez que muitos habitantes dos dois lados da cordilheira nunca sabiam se haviam, ou não, se transferido para um país que não o seu de origem. Outros, sim, estavam a par e por isso mesmo evitavam dar a conhecer o local onde ficavam suas passagens. Eles souberam fazer delas um refúgio para guardar os bens conseguidos ilegalmente e para protegerem-se quando os destacamentos policiais saíam em sua perseguição. ${ }^{18}$

Ser chileno significava ser criminoso. Essa acusação ganhava maior força quando se dizia que a Argentina lhes dera mais oportunidades para seu progresso do que para qualquer outro imigrante. Não se deve ignorar que em fins do século XIX a região ao sul do rio Bio-Bio experimentava um marcado processo de concentração de terra. Esse processo havia empurrado uma parcela considerável da população rural chilena à condição de colonos ou a expulsara para fora do país. Em relação a essa alternativa, essa população podia contar com a área de cordilheira da Patagônia, onde ainda era possível o acesso à terra, ainda que a ocupação fosse precária, e também podia ser contratada como peões nas estâncias que criavam ovelhas, administradas principalmente por ingleses.

Uma parte desse contingente flutuante, sem inserção no esquema de acesso à propriedade e tampouco ao emprego, lançou-se à bandidagem. Muitos grupos de bandoleiros armavam-se no Chile e depois cruzavam o espaço da cordilheira para agir em ambos os lados da fronteira. A eficácia do modelo de ocupação chileno também foi testada na luta contra o bandoleirismo. As oportunidades de perpetrar seus atos dentro do próprio território chileno foram sendo limitadas já na segunda década do século XX. Um informe levado ao governador de Rio Negro de 1906 dava conta do banditismo que parecia estar mudando de país, mas a realidade era que ele agia no interior de um espaço que carecia de fronteiras estáveis e controles aduaneiros, pelo menos até meados da década de 1920:

... aumenta dia a dia o tráfico e, com ele, o roubo de bens e a evasão de delinqüentes que, perseguidos pelas autoridades do Estado limítrofe, ganham nosso território, o qual, não temos dúvidas, será, se nos descuidarmos, em um futuro não distante, o campo de suas correrias e depredaçôes. ${ }^{19}$

Como parte do processo de conquista da Araucania, o sul chileno registrava a presença de uma população excedente. Eric Hobsbawm referia-se a esses fenômenos, afirmando que:

[a] primeira e provavelmente a mais importante das fontes de bandidos acontece nas economias rurais ou de meio ambiente rural, nas quais a demanda de trabalho é relativamente pequena ou que são demasiado pobres para empregar todos seus homens capazes, em outras palavras, nas zonas rurais superpovoadas. ${ }^{20}$

Nos anos 1930, frente aos efeitos dramáticos de sua crise, o campo chileno viu-se novamente sacudido pela expulsão de peóes e pequenos proprietários. Muitos deles tiveram a Argentina como destino. Ali procuraram emprego e, em algumas situações, quando não conseguiam, faziam incursões na atividade criminosa. O mundo rural chileno também viverá um novo momento de convulsão com os levantes dos sindicatos rurais de 1934. Diante da repressão dos grevistas por parte das forças locais e dos militares, houve quem tentasse achar refúgio nos territórios patagônios argentinos. ${ }^{21}$

Os setores dirigentes estabelecidos na Patagônia não fizeram mais do que transplantar uma fórmula discursiva que carecia de originalidade, mas que se havia imposto em outros cenários do país. O criminoso e o bandido era o estrangeiro. Efetivamente, estavam em condiçōes até de identificar a presença de uma "bandidagem internacional". De acordo com Maria Elba Argeri, fica evidente aqui que "a catego- 
ria bandoleiros chilenos obscurecia a realidade" ${ }^{22} \mathrm{O}$ fato é que, com essa afirmação, se insistia que o delito vivia no outro, no forasteiro. Essa concepção ficou evidenciada por ocasião das greves dos peões rurais das estâncias de Santa Cruz, ocorridas em 1921. Não se falou, então, de um conflito motivado por reivindicaçōes, mas sim caracterizado por açōes delituosas, que incluíam sequestros e assaltos, tendo à frente elementos de origem europeia e seguidores, em sua maior parte chilenos, adeptos do maximalismo russo. Falou-se, também, de um complô nascido em solo chileno e que propunha desestabilizar o território patagônio argentino. Ao recuperar essas vozes, Ernesto Bohoslavsky observa que eram comuns os relatos que davam conta de que "os protagonistas desses assaltos e 'malfeitorias' foram 'setores baixos' da sociedade, principalmente estrangeiros, 'bandoleiros', 'facínoras', 'bandidos'. Boholavsky transcreve uma das colunas publicadas em La Nación que "tendia a identificar o grevista com o bandoleiro e o salonero":

Com a colaboração do malfeitor profissional e pelo desamparo que em se encontram os moradores, a reivindicação proletária pôde, muito facilmente, assumir a aparência de algo que, anteriormente, era um assalto de bandidos e, em uma época ainda pouco distante, uma terrível traição. ${ }^{23}$

Eventualmente, essas opiniōes ganhavam força ao ritmo das tensões fronteiriças com o país vizinho que tiveram lugar durante os anos da segunda presidência de Julio Argentino Roca. Viveram-se momentos em que os discursos de um crescente nacionalismo e de uma hostilidade manifesta tornaram-se ainda mais expressivos, fazendo com que importantes contingentes de chilenos preferissem regressar a seu país de origem do que ter de enfrentar condiçôes adversas. Quando os ruídos de guerra deixaram de ser ouvidos, após os acordos firmados durante o segundo mandato presidencial de Roca, muitos chilenos regressaram ao território argentino, sem que por isso o dispositivo discursivo antichileno houvesse sido desmontado.

Porém, não só os chilenos carregaram o estigma de bandidos. Os remanescentes das comunidades indígenas também foram assim rotulados.

Os integrantes das comunidades indígenas, ao apresar animais selvagens ou roubar alguma propriedade, buscavam superar uma situação difícil. Em outras ocasiōes, essas ações representavam a expressão do rancor frente a uma ordem que lhes atribuía o lugar de subordinados. Os grupos indígenas tinham motivos suficientes para adotar represálias, através do delito, quando a ocasião se lhes apresentava. O mesmo acontecia quando eles tinham de se defrontar com o cercamento de seus campos e com a impossibilidade de transitar com seus animais para os pastos de verão; com a expulsão de suas terras e a transferência forçada para outras áreas, extremamente improdutivas; com o fim das boleadas ${ }^{24}$ e do uso comum dos bosques; com a dispersão de seus membros em cenários distantes e desconhecidos; com a hostilidade para com suas formas culturais; com as arbitrariedades cometidas por proprietários brancos ou pela autoridade policial.

Sem omitir o processo de transformação a que estavam submetidas as coletividades aborígines, o sacerdote salesiano Domingo Milanesio expunha as razões que, em sua opinião, tornaram possíveis as condutas consideradas delituosas:

Hoje em dia todos [os indígenas] vão perdendo pouco a pouco os hábitos primitivos. Antigamente, a caça, a pesca, o comércio de seus tecidos, peles e plumas, permitiam-lhes viver com certa folga. Ademais, o domínio absoluto das terras possibilitava que eles se deslocassem em busca de pastos e carnes com as boleadas. Hoje, porém, não podem fazer isso, porque todas [as terras] têm dono (...). Os índios voltariam, assim, a seus antigos vícios, expostos pela necessidade a andar sem rumo, pobres, ignorantes, desnudos famintos, privados até do direito de levantar uma choça para se abrigar, e sem um pedaço de terra que lhes garanta um pouco de pão [...] E quem não teme que, estimulados pela injustiça, pelos rancores e desejos de vingança, acossados pela fome, eles não possam representar sérios perigos à tranquilidade da República? Os bosques da Cordilheira são imensos e impenetráveis, eles conhecem seus refúgios e seus esconderijos, e podem ser temíveis em suas guaridas... ${ }^{25}$ 
Os grupos indígenas estavam condenados a arcar com a responsabilidade por todo e qualquer delito que fosse cometido nas vizinhanças de suas comunidades: o desaparecimento de um animal do rebanho do vizinho branco; a descoberta de um couro de boi sem marca em uma aldeia indígena; o trânsito por um caminho cercado; o corte de cercas; as pegadas de um animal perdido, observadas nas proximidades de um rancho indígena, ou qualquer fato menor. Sua péssima reputação fazia-os merecedores disso. Os discursos tinham um mesmo formato.

\section{Exterminar o bandido}

O temor do bandido exacerbava os ânimos no mundo dos proprietários e das autoridades. A presença de pessoas sem destino fixo era indício da chegada iminente de bandos formados, supostamente, por homens muito bem armados e dispostos a cometer todo tipo de excessos. O extravio de animais, a presença de um cavalo sem cavaleiro e com arreios, a descoberta de restos de equinos ou bovinos com indícios de terem sido desossados recentemente, o tropeço em um cadáver, ou o atraso na chegada de uma tropa de bois ou de vaqueiros com mercadorias, tudo isso também causava temor. Essa mesma inquietude se propagava quando se levantava a possibilidade de as comunicaçóes telegráficas serem interrompidas, ou quando um capataz ou o proprietário de uma fazenda observavam a derrubada das cercas que marcavam os limites da sua propriedade.

Além disso, o alarma soava quando acontecia alguma briga nas proximidades de um local de venda de bebidas e ocasional hospedagem, promovida por recém-chegados, que culminava em certas ocasiōes com tiros ou com um confronto com armas brancas. $\mathrm{O}$ alarma também soava quando acontecia uma fuga de detentos das delegacias ou de uma das prisões da região, tanto em Trelew, Viedma, Roca, quanto em Neuquén. Por exemplo, em 1920, uma tentativa de sublevação colocou em alerta o povoado de Neuquén, que ainda tinha uma forte lembrança da fuga em massa de presos ocorrida quatro anos antes, em maio de 1916.

Que a guarda da delegacia tomasse precauções, porque se acaso houver algo de certo, uma vez que a Cordilheira está infestada de bandidos, o incentivo de saquear o Banco e o comércio poderá ser levado a cabo, maximé se se leva em conta que só existem auxílios a quinhentos quilômetros desta capital, porquanto este Território não conta com guarnição capaz de impedir e proteger eficazmente contra um fato desta natureza, assim o tememos, como o ocorrido em 23 de maio de 1916 e este sem ataque de fora. ${ }^{26}$

Qualquer um desses eventos originava uma espécie de pânico que só era aplacado com a chegada dos policiais que desmentiam esses supostos acontecimentos, ou simplesmente com a passagem do tempo. ${ }^{27} \mathrm{O}$ boato e os desmentidos faziam parte do estado de predisposição em que se achava uma sociedade sensível. A imprensa local refletia esses temores. Sob o título "Os bandoleiros em ação", um semanário destacava que:

[d] esde ontem começou a circular a notícia de que um bando de assassinos vinha cometendo toda sorte de atentados no sul do território. [...] Esta manhã, o governo do território vizinho carecia de notícias que não fossem as de um assalto levado a cabo na casa de Flores \& Criado. Também nos asseguraram que na vizinha capital havia inusitado movimento de forças. ${ }^{28}$

No mês seguinte, voltaram a circular rumores com o mesmo tom:

Na semana passada circulou a notícia da chegada de um enorme bando de salteadores ao qual se haviam juntado contingentes apreciáveis de índios. A informação acrescentava que, no caminho, eles cometeram toda sorte de atentados e depredações [...]

De nossas investigações pudemos constatar que se trata de uma coisa sem maior transcendência e de consequências benignas, diremos assim, já que não há que lamentar outra coisa senão alguns roubinhos e o susto que dá a presença de gente mal vestida. ${ }^{29}$ 
No começo da década de 1930, o bando comandado por Juan Bautista Vairoleto realizou vários assaltos. O medo dos moradores de uma ampla franja territorial de Rio Negro e Neuquén era sentido com muita intensidade. As ações estrepitosas do bando e o fracasso dos grupos que saíram em sua perseguição, juntamente com destacamentos policiais de vários territórios, ampliavam ainda mais o medo e a desconfiança perante a presença de homens a cavalo e de desconhecidos. ${ }^{30}$

Esses temores forneciam a justificativa para a realização de uma autêntica caçada contra aqueles sujeitos considerados bandidos extremadamente perigosos.

Elaborou-se, portanto, um discurso que justificava o extermínio de quantos bandidos cruzassem o caminho das forças policiais. Foi o caso de Pedro Sánchez, que se dedicava ao roubo de gado na zona central do território neuquino, na área da cordilheira, e que em seguida comerciava nas localidades chilenas. Ele havia construído uma temível reputação, razão pela qual era alvo de muitas precauções. Sánchez havia sido um dos poucos fugitivos que conseguira não ser recapturado por ocasião da fuga em massa da prisão de Neuquén, em 1916. Ele foi capaz de evitar, por um tempo, a perseguição policial cruzando a fronteira em direção ao Chile. Só foi "caçado" quatro anos depois.

Embora se acredite que não seja muito conhecido pela polícia argentina desta região, o bandido Pedro Sánchez havia feito sentir suas habilidades de ladrão audaz e temível não mais apenas na região de Icalma, na República do Chile, mas também na porção limítrofe ao lago Alumine, em nosso país; assim, como não há um único morador daquela [área] que não conheça Sánchez de nome e muitos de vista, a quem temem por seus feitos, sobretudo pela forma audaz e, no entanto, misteriosa com que atua. Quanto à vida que levava no vizinho País do Chile, ela é mais do que tudo de ocultamento em seus últimos tempos, devido à perseguição que havia merecido por parte das autoridades chilenas. Suas habilidades, porém, já não se reduziam ao roubo, mas também ao saque; a propósito, contam-se muitas aventuras e fatos dos quais Sánchez foi protagonista, sua arma predileta que não deixava nunca e que usou com muita frequência e, segundo aqueles que o conhecem, carregava uma arma das melhores. ${ }^{31}$

Sua fama não lhe impediu de ser descoberto e após uma prolongada perseguição, enquanto dois membros do seu bando conseguiam fugir, Sánchez foi abatido por um tiro certeiro de carabina, em um obscuro episódio, que teve como único testemunho o policial que lhe causou a morte. Se, por um lado, o documento judicial que reproduz parcialmente o fato contém parte das opiniões registradas entre as vítimas de seus ataques, por outro, revela-se como um dispositivo determinista destinado a impor a lógica da repressão, quando se tratava de temíveis assaltantes e ladrôes de gado. $\mathrm{O}$ fato de alguns terem colocado em dúvida as circunstâncias de sua morte respondia às tentativas de legitimar uma opinião que pode ter sido fabricada; tratava-se, em outros termos, apenas de uma construção discursiva que, posta na boca dos proprietários e moradores "honestos", transformava-se em verdade para o funcionário judicial. Havia que esclarecer se a Justiça se encontrava diante de um homicídio ou diante de uma ação policial justa. A balança inclinou-se decididamente a favor da segunda. A polícia havia agido de acordo com seu papel, e já havia sido dita a última palavra sobre a questão.

Uma vez identificado o bandoleiro, se ele não se entregava imediatamente ao comando de "Alto!", a polícia e os moradores armados recorriam à linguagem das carabinas. Daí que poder "antecipar-se" ao bandoleiro era o melhor expediente para terminar com suas incursóes e, além disso, proteger a vida dos homens que integravam o destacamento persecutório.

Outro caso foi o de Pedro Gutiérrez, perseguido até o interior do território chileno. Na colônia de Hueñivales, no caminho de Cura Cautín, ele encontrou a morte nas mãos dos galos (nome pejorativo dado aos carabineiros chilenos). A imprensa transandina seguiu muito de perto a fuga e a posterior morte deste foragido.

Ao bando de Gutiérrez, identificado como o cabeça, eram atribuídos numerosos assaltos e roubos. A imprensa lhe imputava oito assassinatos, mas apenas três puderam ser comprovados. Um mês antes de ser abatido pelos carabineiros, o bando comandado por Gutiérrez se viu envolvido em um último 
episódio sangrento. Foram dois os homicídios cometidos. Carregando um butim em dinheiro, armas e peças de vestuário, os homens alcançaram a fronteira chilena. $\mathrm{O}$ bando se dispersou sem saber que, do lado argentino, um destacamento policial começava a se organizar para tentar sua captura. Os perseguidores seguiram suas pistas cruzando a fronteira, depois de assegurada a decidida colaboração das autoridades policiais chilenas. Várias semanas mais tarde, Pedro Gutiérrez acabou sendo localizado em uma via pública, acompanhado de uma menor que declarou ter sido raptada. Ele não acatou a voz de prisão dos dois agentes chilenos e do sargento argentino que os acompanhava, mas, obrigado a deter sua marcha, se escondeu atrás de seu cavalo, morto por um tiro proveniente das armas disparadas por seus perseguidores. O bandido, surpreendido, respondeu ao fogo com sua carabina Winchester. O combate durou muito pouco tempo e produziu uma única baixa, o próprio Pedro Gutiérrez. Havia mais de cem balas em sua mochila, e algumas peças de seu último roubo em território argentino. A autópsia revelou que o corpo havia recebido um total de cinco tiros.

El Diario Austral de Temuco não poupou elogios à ação dos policiais chilenos. Em contrapartida, avaliou com ironia a participação do sargento argentino que os havia acompanhado na escaramuça. Consultado pelo jornalista para que explicasse porque não havia respondido ao fogo de Gutiérrez, o sargento respondeu que pouco tinha a fazer, já que os carabineiros chilenos estavam fazendo tudo bastante bem, o que fez com que "as palavras do policial argentino, assim que foram divulgadas, tenham sido comentadas de forma jocosa". ${ }^{32}$ Os chilenos podiam estar orgulhosos do poderio de suas forças policiais que pareciam ser muito profissionais, se comparadas às dos argentinos, as quais, segundo opinião generalizada, calçavam luvas de pelica para enfrentar essas formas de delinquência.

$\mathrm{Na}$ verdade, desde a década de 1910, o fenômeno do bandoleirismo nas zonas central e sul do Chile havia perdido a intensidade de antigamente. Sem dúvida, a eficiência de seus corpos policiais, a expansão das comunicações, o avanço da urbanização, o forte desenvolvimento da economia agrária e a dura disciplina imposta aos trabalhadores no campo, juntamente com o desenvolvimento da mineração do carvão, no sul, e do salitre e do cobre, no norte, parecem ter sido as principais causas que limitaram a presença dessa massa flutuante de população, deixando escassa margem para a ocorrência de pilhagens naquela região. ${ }^{33}$ No entanto, e apesar da suposta retração dessas modalidades delituosas, por volta dos anos 1930 houve uma renovação do bandoleirismo, devido aos problemas ocorridos no campo chileno e em seu mercado de trabalho, em consequência da crise de 1930, e de uma espécie de mobilização rural dirigida pelos comunistas desse país. Esse "banditismo", porém, estava mais próximo de uma revolta agrária.

No caso da perseguição e morte de um número significativo de bandoleiros, circulava sigilosamente entre os contingentes policiais uma ordem de execução sumária, quando se tratasse de bandidos perigosos. Como parte dessa decisão, os quadros superiores asseguravam a liberdade de ação de seus subordinados. A prisão desses bandoleiros vivos foi menos usual do que o confronto com eles, seguido de morte, sobretudo quando rechaçavam as forças policiais, ou, como aconteceu em várias oportunidades, quando eles tinham causado a morte de algum agente. A ordem de "meter bala primeiro" estendia-se a outras situaçôes em que houvesse risco de o crime ficar fora de controle. Na prática, o cumprimento dessas instruções por parte das forças policiais foi aplicado depois da evasão e posterior perseguição de mais de cem presos da prisão de Neuquén, no final do outono de 1916.

No primeiro confronto entre os dois lados, três guardas perderam a vida, outros tantos saíram feridos, e houve um morto entre os sublevados. Em seguida, vários moradores foram atingidos, um comerciante assassinado e foram feitas mais vítimas, entre policiais e prisioneiros fugitivos. Apenas uma semana depois dos acontecimentos da capital neuquina, ocorreu outra fuga, de maior repercussão, nas proximidades de Zapala. O grupo mais importante de fugitivos, um total de 17 homens que tentava alcançar o território chileno, acabou sendo alcançado na metade do caminho por um destacamento policial, em Zainuco, lugarejo situado na parte central do território neuquino. Morto seu líder no primeiro combate, os demais foram definitivamente dominados, já que haviam abandonado as armas roubadas durante a fuga. Os policiais tomaram a precaução de dividir o grupo em dois. 
Um primeiro contingente, a metade dos recapturados, foi imediatamente mandado de volta para a prisão de Neuquén, enquanto os outros tiveram de esperar sua transferência efetiva. No entanto, o último grupo nunca regressou à unidade carcerária. Os oito detidos foram executados sumariamente no mesmo lugar onde se haviam rendido. Segundo os despachos policiais, os fugitivos tinham tentado desarmar um dos guardas e por isso os demais se viram na obrigação de abrir fogo. Não houve nenhuma baixa entre os integrantes do destacamento policial. Longe daquela matança, outros grupos de fugitivos também foram alcançados. Alguns ofereceram resistência e enfrentaram as forças policiais. Nessas situações, vários presos foram igualmente mortos.

Mais para o sul, na zona da Cordilheira, a situação não parecia apresentar-se de maneira muito diferente, sobretudo porque a perseguição dos temerários bandoleiros havia sido encomendada aos corpos móveis da polícia fronteiriça. Foi o que ocorreu no caso de William Wilson e Robert Evans, que encontraram a morte em circunstâncias em que apenas o contingente policial pôde testemunhar os fatos. Aqui também o mito e o temor de sua presença entre os moradores pareceram impor-se à realidade, já que esses homens foram "vistos" simultaneamente em território neuquino, rionegrino, mendocino, puntano e até no Chile. O certo é que a dupla foi alcançada no lugarejo de Rio Pico, depois de uma perseguição de mais de seis meses movida pelo melhor destacamento policial de Chubut. Evans era, sem dúvida, o homem mais procurado do grupo liderado por Butch Cassidy e Sundance $\mathrm{Kid}^{34}$ durante os anos em que estiveram na região. Os bandidos foram localizados em Rio Pico, nos primeiros dias de dezembro de 1911, emboscados e mortos. Participaram da ação uma dúzia de policiais muito bem equipados, que apesar de surpreender e superar em poder de fogo os bandoleiros, não conseguiram se esquivar das balas dos fugitivos, que provocaram a morte de um guarda, deixando outro gravemente ferido.

Uma vez mais, os testemunhos monocórdios dos policiais repetiam que tinham sido obrigados a disparar diante da obstinada resistência articulada pelos bandidos norte-americanos. Naquela época, muitos acreditaram ver na morte de Evans e Williams o fim dos homens da "Quadrilha Selvagem", como ficara conhecido em seu país de origem o grupo comandado por Cassidy e Kid em sua longa trajetória de delitos.

Não há dúvida de que as forças policiais não davam uma segunda chance. Em outro episódio, quando o perigo de assalto e a ameaça de assassinato do comissário, do juiz de paz e de um conhecido comerciante espalharam-se entre os moradores de Nahuel Huapi, nos últimos dias de 1904 e nos primeiros dias do ano seguinte, a resposta não se fez esperar. $\mathrm{O}$ comissário local foi muito preciso ao declarar o motivo pelo qual se vira obrigado a desfechar um tiro em Victorio Ruiz dentro das dependências policiais. Segundo ele, Ruiz

...pretendia evadir-se pela segunda vez. (...) [Ele] era um verdadeiro bandoleiro de péssimos e temidos antecedentes em todo este departamento, especialmente no lugarejo denominado Costa do Rio Caleufú, onde habitualmente vagabundeia e onde ameaçou de morte vários moradores. ${ }^{35}$

\section{Bandoleiros do sul como rebeldes primitivos?}

A Patagônia, a exemplo de outras regiões da Argentina, careceu de um tipo de bandoleiro que reunisse os atributos de um Robin Hood da floresta de Sherwood, ou mesmo de um Segundo David Peralta, mais conhecido como "Mate Cosido", da região do Chaco; de Isidoro Velázquez, no litoral; ou de Juan Bautista Vairoleto, o homem mais procurado em terras pampeanas, ${ }^{36}$ cuyanas, $^{37}$ puntanas ${ }^{38} \mathrm{e}$ rionegrinas. ${ }^{39}$ Contudo, a região contou com um tipo de bandido "anônimo", cujas ações foram menos ruidosas e se desenrolaram, cronologicamente, próximas uma das outras.

Eric Hobsbawm assinala a existência de dois tipos sociais "ideais", que deram forma, simultaneamente, a outras tantas variantes: o bandoleirismo social, ou os "bons" bandidos, e o banditismo criminoso. Os bandidos sociais seriam os rebeldes de qualquer sociedade, encarnando o protesto primitivo e a desobediência diante de uma realidade que se sustenta a partir do predomínio de um setor social sobre 
outro. Em contrapartida, os outros, os bandidos criminosos, ao seguir o caminho da colaboração com as classes dominantes, fazem sempre parte do sistema. Sob essa dupla caracterização, o historiador britânico buscava destacar a natureza social do funcionamento do bandoleirismo e, sobretudo, suas implicações políticas. A dimensão política devia-se à própria existência do bandido, já que este expunha o rosto da desobediência à forma através da qual o Estado e suas classes dominantes procuravam instituir um modelo de coordenação para toda a sociedade.

A sociedade que viu nascer os bandidos sociais lhes outorgou carta de cidadania, além de respeito, consideração e admiração, enquanto as gerações seguintes lhes devotaram uma veneração quase religiosa. Por sua vez, os bandoleiros criminosos foram repudiados e expulsos do "povo". Comparados com estes, os bandoleiros sociais mereciam ser admirados por serem "heróis, valentes, justos e vingadores". Os "bandidos criminosos" foram mostrados como ladrões que não tinham outra preocupação a não ser a de se apropriar de quantos bens e valores estivessem ao seu alcance, fossem do pobre ou do rico, mesmo quando, para isso, tivessem de assassinar a sangue frio. Como criminosos comuns, nunca tiveram consideração para com suas vítimas. É bem verdade que uma parcela da sociedade teria feito uma avaliação diferente, caso esses homens tivessem sido levados a cometer seus atos delituosos por necessidade, ou devido a questóes ligadas à ruptura dos valores e das regras da comunidade, ou se não tivesse suspeitado de que muitos deles eram mobilizados pelos poderosos, convertidos em meros instrumentos das intermináveis disputas por recursos e poder entre membros adversários dos próprios setores sociais dominantes.

Alguns dos bandidos criminosos provinham dos setores rurais marginais, ao passo que outros, por suas condutas, pertenciam àquele setor da sociedade que sempre procurou trilhar um caminho mais rápido - nem sempre com pouco esforço, mas sim com muitos riscos - para ampliar e fortalecer os pilares do seu poder econômico. A impunidade alcançada em seus acertos com comissários e juízes também lhes permitiu encobrir muitas de suas ações. Entre eles, encontra-se um número significativo de proprietários que escolheram esse modo de vida. Quer seja como homens do poder, manipulados por terceiros, quer simplesmente como criminosos, os "bandidos criminosos" converteram-se em servidores ou parte do Poder, e sob essa ótica eram vistos como inimigos dos setores subordinados. Eram e continuariam sendo somente vilóes. E seus atos repugnantes, depredadores, cruéis e, sim, criminosos.

Já os bandoleiros sociais, por seu turno, mereciam maior consideração. Mantiveram uma relação de compreensão e comunicação com a comunidade na qual levavam a cabo suas ações. No interior de uma coletividade carente de recursos, eles eram vistos como parte integrante, e, acima de tudo, como exemplos de resistência. Seus "crimes" foram, inclusive, elevados à condição de façanhas e assim avaliados pela ampla consideração que gozavam junto à opinião das classes populares. Roubar o rico para dar ao pobre, ajustar contas com um comerciante enganador, responder à afronta pública de um funcionário explorador ou de um patrão cruel, tudo isso fará parte do mito popular. Obrigado a viver na ilegalidade, esse tipo de bandido se convertia na mão vingadora do povo; consequentemente, os ricos deviam temê-lo, e os pobres, admirá-lo. Quando chegava a hora da morte comprovada, era chorado, e em muitos casos era elevado à dimensão de santo milagroso. A memória popular se encarregava do resto, de fazer respeitar sua biografia e de reinventar seus crimes.

Os casos identificados nessas isoladas regiōes do sul argentino pareceram guardar uma grande distância dos bandoleiros sociais de Hobsbawm. Responderiam ao modelo do bandoleiro criminoso ou seriam os rebeldes primitivos?

Não se pode afirmar, com certeza absoluta, que o bandido criminoso tivesse se imposto sobre o tipo "social" no extenso território argentino. Muito poucos bandidos que operavam em grande parte do espaço das províncias do Chaco e Corrientes, da região pampeano-patagônia, especialmente da Cordilheira dos Andes, foram capazes de defender ideais e, menos ainda, de terem sensibilidade para com os seus. Houve, sim, homens, e muito poucas mulheres, que se colocaram fora da lei, roubando indistintamente a quem sobrava para viver e também aqueles menos afortunados, com o claro objetivo de incre- 
mentar seus recursos ou simplesmente para viver um dia a mais. E houve também aqueles dispostos a matar para se assegurar de um bom butim ou para acertar as contas de velhas desavenças pessoais.

A ausência de mitos heroicos construídos em torno dos bandidos que assolavam essa região, com capacidade de construir o imaginário do "bom bandido" entre os membros das comunidades rurais, parece confirmar este ponto. Deve-se assinalar, sem dúvida, que é provável que a conversão dos crimes desses bandidos em façanhas e sua entronização como heróis ou vingadores populares, inclusive como "líderes da libertação", não se tenham cristalizado inteiramente nos territórios patagônios e sim em uma parte do Chile, confundindo-se no mundo delituoso chileno mais amplo, onde efetivamente o bandoleirismo social parece ter alcançado carta de cidadania.

$\mathrm{Na}$ Patagônia argentina, existiu um imaginário do bandoleiro social. Nesses vastos cenários de uma sociedade em situação de fronteira, construiu-se um imaginário sobre o bandoleirismo "remontando" ao século XIX, como o ocorrido com os bandidos guerrilheiros dos tempos da independência, os irmãos Pincheira. Estes continuaram sendo uma "lembrança viva" no norte da província patagônica. Também em seu extremo sul houve outros bandoleiros renomados. Mais de meio século depois, acontecia o mesmo com Juan Bautista Vairoleto. Este, ou algum membro de seu bando, foi "visto" algumas vezes na extensa geografia patagônica, exercendo sua suposta vocação vingadora.

No entanto, a presença necessária dessas representações sobre os bandidos de um "distante oeste" patagônio não se refere obrigatoriamente a esse tipo de bandoleirismo, nem tampouco àquele que se destaca exclusivamente pelo passado criminoso. Muitas das ações revelam o mal-estar de uma sociedade rural que enfrentou o conflito como expressão da apropriação desigual e da desigual distribuição de terra e outros bens materiais, do mesmo modo que outros bens menos visíveis, mas de grande impacto vital, como a honra e a cortesia.

\section{Tradução: Sérgio Lamarão Revisão técnica e edição: Maria Aparecida Rezende Mota}

\section{Notas}

${ }^{1} \mathrm{O}$ presente estudo foi originalmente escrito para a intervenção do autor na mesa-redonda "Margens do rural”, no âmbito do Simpósio Internacional História e Margem, promovido pelo Programa de Pós-graduação em História Social da Universidade Federal do Rio de Janeiro (UFRJ), entre 18 e 20 de outubro de 2010.

${ }^{2}$ Porfiriato: referência ao longo período do governo de Porfírio Díaz (1830-1915), presidente do México, entre 1884 e 1911 (Nota do Editor). Ver VANDERWOOD, Paul J. Los bandidos de Manuel Payno. In: Historia Mexicana, v. XLIV, julho-setembro, 173, El Colegio de México, México, 1994, p. 130.

${ }^{3}$ ARGERI, Maria E. e GHÍA, Sandra. Resistiendo a la Ley: ámbitos peligrosos de sociabilidad y conducta social. Gobernación de Rio Negro, 1880-1930. Anuario do IEHS, VIII, Tandil, 1993.

${ }^{4}$ Juan Bautista Vairoleto (1894-1941). Juntamente com Isidro Velázquez e David Segundo “Mate Cosido” Peralta, ele é figura destacada entre os bandoleiros do século XX. Vairoleto viveu na ilegalidade durante as décadas de 20 e 30 . Em 1919, matou um agente policial de La Pampa. Depois de ter passado um tempo na prisão, serviu como segurança de um comitê do partido Unión Civica Radical. Já sem a proteção política, assaltou vários estabelecimentos e armazéns rurais, buscando refúgio entre camponeses e colonos. Manteve vínculos com grupos anarquistas e em 1937, juntamente com "Mate Cosido", assaltou a empresa inglesa La Forestal, no território do Chaco. Suas ações se estenderam por todo o centro-sul da região pampeana e parte do norte da Patagônia.

${ }^{5} \mathrm{Na}$ Argentina, foi o pesquisador Marcelo Gavirati que conseguiu fazer uma reconstituição da passagem pela Patagônia da dupla formada por Cassidy e Kid. Esses estudos foram atualizados no livro Buscados en la Patagonia, La Bitácora Patagónica. Buenos Aires: Patagonia Sul Libros, 2005.

${ }^{6}$ Um cronista policial assim registrou uma dessas ações: "O lugarejo denominado Paso Chacabuco - pertencente a Paso Flores, na qual reside uma numerosa população trabalhadora - tornou-se, nos últimos dias, o novo cenário de uma dessas tragédias misteriosas de que vem sendo vítima o território, profundamente afetado pela magnitude dos sangrentos acontecimentos que com desesperante frequência vem sendo produzidos em seu seio, e na qual o chumbo homicida foi miseravelmente conjugado com seu mais vil e vergonhoso destino, tomando de surpresa a tranquilidade familiar de lares felizes que 
hoje vivem a odisseia fúnebre do mais áspero e doloroso luto, sacrificando, com segurança, vidas preciosas de homens úteis à sociedade e dignos de consideração para todos. No acontecimento de Paso Chacabuco caíram sob a violência mortal do projétil sinistro, disparado traiçoeiramente, três homens valorosos, cujas vidas honestas, dedicadas a dar ao ambiente em que atuavam melhores perspectivas de progresso, moviam-se ao calor dos sãos ideais e cumpriam um destino benfeitor dentro da esfera de suas energias". La Nueva Era, Carmen de Patagones-Viedma, 21 de abril de 1928, p. 2.

${ }^{7}$ La Nueva Era, Carmen de Patagones - Viedma, 28 de abril de 1928, p. 1.

${ }^{8}$ Río Negro, General Roca, 30 de junho de 1932.

${ }^{9}$ LAPALMA, Oscar Fermín. Leyenda do Limay. Impresiones de um raid náutico por los ríos Limay y Negro. Buenos Aires: Talleres Gráficos Porter, 1934, p. 106-107.

${ }^{10}$ Oscar Fermín Lapalma, funcionário da Justiça letrada do norte da Patagônia reportava-se aos fatos que Juan Bautista Vairoleto havia protagonizado, referindo-se a ele como "um simples criminoso", muito distante de uma figura que merecesse destaque. O cronista fazia uma menção especial a Vairoleto por ter sido responsável pelo assassinato, a sangue frio, de um vendedor ambulante. Suas palavras - ao contrário de muitos - negavam qualquer condescendência ao bandoleirismo destas regiōes: “Aqui está a famosa 'façanha' do famoso bandoleiro, ao qual se atribui um valor temerário. Não, esse bandido deve ser como todos, sanguinário e covarde, com mais astúcia [talvez] ou mais sorte do que outros para iludir a ação policial”. Río Negro, General Roca, 30 de junho de 1932, p. 3.

${ }^{11}$ Os jornais da região do Rio Negro deram ampla cobertura aos acontecimentos. El Tribuno e o Río Negro dedicaram várias colunas, em fins de outubro e princípios de novembro, em que davam conta do trajeto de Elmes. Passados quase 70 anos de sua morte, alguns moradores de General Roca asseguram que o ex-companheiro de Vairoleto faleceu depois de levar uma vida sem sobressaltos, trabalhando em uma tapeçaria da cidade. O mito de que o bandoleiro nunca morre está presente nesses depoimentos.

12 "Assim como são atribuídas aos seus crimes as qualidades de amoral, feroz e aventureiro, a superstição popular vê neles características de crente religioso, caridoso, valente, engenhoso, quando não de santo varão de uma virtude extemporânea e caprichosa, como [é o caso] de Bazán Frias”. In: Revista de Criminología, tomo XIII. Buenos Aires, 1926, p. 36. Sabe-se que, anos mais tarde, o mesmo acontecerá com figuras como Vailoreto e Mate Cosido.

${ }^{13} \mathrm{O}$ conceito de bandoleiros santificados foi tomado de Hugo Chumbita, maior especialista na vida e na obra de Vairoleto. Chumbita afirma: "O fenômeno espontâneo da canonização centra-se em figuras menos notórias, como se tais crenças desempenhassem um papel compensatório, resgatando do esquecimento os heróis mais humildes”. In: Jinetes Rebeldes. Buenos Aires: Vergasse, 2000, p. 218.

${ }^{14}$ De acordo com os censos nacionais, o peso dos imigrantes chilenos em Neuquén era esmagador. O censo de 1895 revelou a presença de $61,2 \%$ de chilenos no total da população do território, enquanto que o de 1914 refletia o início de um processo de retração desse contingente. Para esse ano, o contingente transandino situou-se em torno de 40,9 \%. No censo territorial seguinte, em 1920, o percentual de população chilena foi de 35,6 \%. Se bem que é certo que essa diminuição relaciona-se à argentinização dos descendentes de muitos desses chilenos, a chegada de argentinos provenientes de outros territórios e províncias e a presença de imigrantes de origem europeia fizeram com que 86,15\% dos estrangeiros assentados na região ainda fossem de origem transandina. Por outro lado, se se observa a incidência dos nascidos no Chile no total da população estrangeira, a ausência de outras nacionalidades diferentes da chilena entre os implicados em ações criminosas deve ser explicada por sua limitada participação no panorama demográfico da região. Efetivamente, em 1895 a população chilena representava $98,32 \%$ do total dos estrangeiros e sua participação continuou sendo significativa nos censos seguintes: no de 1914 foi de 88,64 \% e nos censos territoriais de 1920 e 1931, foi de 86,15\% e de 78,63\% respectivamente. Cf. Crisafulli, Gustavo e Bertani, Luis, La evolución de la población neuquina 1894-1947, Neuquén, 1991, mimeo.; e Frapiccini, Alina et alii. Migración y fluctuaciones del mercado de trabajo: los trabajadores chilenos de Neuquén, 1884.1930. Estudios Migratorios Latinoamericanos, n. 30. Buenos Aires, agosto de 1995.

${ }^{15}$ Memória do governador Lisandro Olmos, 1900, p. 490.

${ }^{16}$ Río Neuquén, Chos Malal, ano 1, n. 2, 1900, p. 1.

${ }^{17}$ Citado por Graciela Noelia Suarez, "La policía en la región andina rionegrina: los cuerpos especiales y la incorporación de particulares”. Apresentação feita na VIII Jornadas Interescolas/Departamentos de História. Salta, 2001.

18 "Os bandidos, em seus esconderijos dos dois lados das linhas fronteiriças, estão certos de que ali nenhum perigo os ameaça, e quando se apresentam circunstâncias propícias para realizar seus malfeitos, sem que as autoridades policiais possam impedi-los, caem sobre os povoados - fazendas, casas de comércio -, matam homens e crianças, sequestram mulheres, roubam gado, e recorrem ao fogo para apagar suas pegadas". La Voz del Sud, Viedma, 3 de maio de 1928, p. 1.

${ }^{19}$ Citado por SUÁREZ, Graciela N. La seguridad y el orden: el accionar policial en la región. In: REY, Héctor (Org.). La cordillera rionegrina. Economía, Estado y sociedad en la primera mitad del siglo XX. Viedma: Editorial 2010, Bicentenario, 2005, p. 88.

${ }^{20}$ HOBSBAWM, Eric. Bandidos, Barcelona: Ariel, 1976, p. 29. 
${ }^{21}$ No princípio dos anos trinta do século passado, a região do Bio-Bio foi protagonista de um novo processo de delimitação e formalização da propriedade de terras. A consequência desse processo foi o congelamento de novos assentamentos e em seguida o desalojamento de muitos camponeses, sobretudo após a queda do governo de Ibañez. A isso se somaram as dificuldades enfrentadas por numerosos contingentes de trabalhadores assentados na região, que trabalhavam na construção de túneis e na mineração. A constituição de sindicatos de trabalhadores agrícolas e a exposição de suas demandas geraram um forte enfrentamento com os latifundiários e as autoridades. A repressão não se fez esperar. 1934 foi um ano crítico para os trabalhadores, em virtude da onda de repressão que provocou a prisão e a execução sumária de centenas de pessoas.

${ }^{22}$ ARGERI, Maria Elba. "De guerreros a delincuentes. Una frontera étnica para la exclusión social. Territorio de Río Negro a principios del siglo XX”. Apresentação feita durante as Jornadas Interescuelas/Departamentos de Historia, realizadas na Pampa, 1998. Mimeo, p. 16.

${ }^{23}$ BOHOSLAVSKY, Ernesto. El complot patagônico. Nación, conspiracionismo y violencia en el sur de Argentina y Chile (Siglo XIX y XX). Buenos Aires: Prometo, 2009, p. 121.

${ }^{24}$ Atividade muito comum no sul do continente que consiste em arremessar boleadeiras e prender com elas (um animal). (Nota do Editor).

${ }^{25}$ MILANESIO, Domingo. La Patagonia, lingua, industria, costumi e religione dei Patagoni. Buenos-Aires: Escuela Profesional de Tipógrafos del Colegio Pio IX de Artes y Oficios, 1898.

${ }^{26}$ AJLN. Expediente 127 bis, ano 1920, folio 123.

${ }^{27}$ Operavam certos componentes geradores de pânico similares àqueles que Georges Lefebvre magistralmente descreveu em sua célebre obra sobre a França revolucionária. LEFEBVRE, Georges. La revolución francesa y los camponeses. Buenos Aires: Paidós, 1974.

${ }^{28}$ Rio Negro, General Roca, 24 de fevereiro de 1921, p. 3.

${ }^{29}$ Rio Negro, General Roca, 3 de março de 1921.

${ }^{30} \mathrm{O}$ jornalista do diário Rio Negro parecia se dar conta do sentimento imperante na região, além de fazer um bom registro do fracasso da presença policial: "Após as denúncias recebidas pela polícia, foram enviados vários destacamentos de La Pampa e Neuquén na busca e perseguição do bandoleiro Vairoleto. Até agora, parece que um dos destacamentos policiais conseguiu identificar Vairoleto nas imediações de Cervantes, perseguiu-o e trocou alguns disparos de armas com o delinquente, que poderia ter sido detido ou morto porque ia em má cavalgadura; ele se deteve a algumas centenas de metros de seus perseguidores; ajustou a montaria tranquilamente e se afastou do lugar, rumo ao altiplano, convencido que a perseguição havia sido contida. A polícia acredita estar novamente em seu encalço e vê com otimismo a captura do delinquente". Rio Negro, General Roca, 23 de agosto de 1934.

${ }^{31}$ AJLN, Expediente n. 657, Ano 1920, Folio 2 e reverso.

${ }^{32}$ El Diario Austral, Temuco, República de Chile, 19 de abril de 1928, p. 2.

${ }^{33}$ PINTO RODRIGUEZ, Jorge. El bandolerismo en la frontera, 1880-1920, em VILLALOBOS, Sergio e PINTO, Jorge (compiladores). Araucanía. Temas de historia fronteriza. Temuco: Ediciones Universidad de la Frontera, 1989.

${ }^{34}$ As forças da Polícia de Fronteira demoraram a dar sepultura aos corpos de Evans e Willians. Convencidas de que pertenciam a Cassidy e a Kid, queriam maximizar seu "triunfo" contra o bandoleirismo. No entanto, essas esperanças se desfizeram porque os moradores reconheceram os corpos. GAVIRATI, Marcelo. Buscados na Patagonia. La Bitácora Patagónica. Buenos Aires: Patagonia Sul Libros, 2005.

${ }^{35}$ AJLN. Expediente n. 17, ano 1905, folio 13.

${ }^{36}$ N. do. T.: O autor refere-se à província de La Pampa.

${ }^{37}$ N. do. T.: O autor refere-se à região do Cuyo, situada no centro-oeste da Argentina e que abrange as províncias de Mendoza, San Juan e San Luis.

${ }^{38}$ N. do. T.: O autor refere-se à região que corresponde ao centro-norte da província de San Luis.

${ }^{39}$ Embora o "território" privilegiado por Juan Bautista Vairoleto tenha sido a fronteira pampeano-rionegrina e a região cuyana, seu mito foi capaz de projetar-se sobre esta região, especialmente em Rio Negro e, com o correr dos anos, também no mundo rural neuquino. 


\section{Referências}

ARGERI Maria Elba \& CHIA, Sandra. Resistiendo a la ley: ámbitos peligrosos de sociabilidad y conducta social. Gobernación de Río Negro, 1880-1930. Anuario IEHS, n. 8, Tandil, 1993.

ARGERI, María Elba. De guerreros a delincuentes. Una frontera étnica para la exclusión social. Territorio de Río Negro a principios del siglo XX. Apresentação feita durante as Jornadas Interescuelas/Departamentos de Historia realizadas en La Pampa, 1998. Mimeo.

. La construcción de un mito: Elena Greenhill, la inglesa "bandolera" de la Patagonia. Entrepasados Revista de Historia n. 17. Buenos Aires, final de 1999.

lona, 1999.

Sociabilidad pecaminosa: Gobernación de Río Negro 1880-1930. Boletín Americanista n. 49. Barce-

BANDIERI, Susana. Historia de la Patagonia. Buenos Aires: Sudamericana, 2005.

BANDIERI, Susana (Org.). Cruzando la Cordillera. Neuquén: CEHIR, 2001.

BAYER, Osvaldo. Los vengadores de la Patagonia trágica. Buenos Aires: Galerna, 1974.

BOHOSLAVSKY, Ernesto. Bang, Bang: El Mundo del Delito en el Territorio del Neuquén, 1900-1930. monografía de licenciatura, 1998, Mimeo.

. El complot patagónico. Nación, conspiracionismo y violencia en el sur de Argentina y Chile (Siglo XIX y XX). Buenos Aires: Prometo. 2009.

CAIMARI, Lila. Apenas un delincuente. Crimen, Castigo y Cultura en la Argentina, 1880-1955. Buenos Aires: Siglo XXI, 2004.

CARRI, Roberto. Isidro Velázquez, formas prerrevolucionarias de la violencia. Buenos Aires: Colihue, 2001

CHANETON, Juan Carlos. Zainuco, los precursores de la Patagonia Trágica. Buenos Aires: Galerna, 1992.

CHUCAIR, Elías. La inglesa bandolera y otros relatos patagónicos. Neuquén: Siringa Libros, 1983.

CHUMBITA, Hugo. Jinetes Rebelde. Historia Social del Bandolerismo en la Argentina. Buenos Aires: Javier Vergara Editor, 2000.

. Ultima frontera, Vairoleto, vida y leyenda de un bandolero. Buenos Aires: Planeta, 1999.

CONTRERAS, Juan E. Violencia y criminalidad en la Araucanía, 1860-1910. Nutran, VII, Santiago de Chile, 1991.

DAITSMAN, Andy. Bandolerismo: mito y sociedad. Proposiciones, n. 19. Valparaiso: Ediciones Sur, 1990.

DI LISIA, María Silvia \& BOHOSLAVSKY, Ernesto (ed.). Instituciones y formas de control social en América Latina 1840-1940. Buenos Aires: Prometeo Libros, 2005.

DIEZ, María Angélica et al. Conflictos y delitos en la etapa de formación de la sociedad pampeana (1885-1922). In: COLOMBATO, Julio A. (coord). Trillar era una fiesta. Santa Rosa: Instituto de Historia Regional Facultad de Ciencias Humanas Universidad Nacional de La Pampa, 1995.

FARGE, Arlette. Algunos instrumentos para reflexionar sobre la historia de la violencia. Anuario del IEHS, n. 10, Tandil, 1995.

GAVIRATI, Marcelo. Buscados en la Patagonia. Buenos Aires: La Bitácora Patagónica Patagonia Sur Libros, 2005.

HOBSBAWM, Eric J. Rebeldes Primitivos, estudios sobre las formas arcaicas de los movimientos sociales en los siglos XIX y XX. Barcelona: Ariel, 1983. [ed. bras. Rebeldes primitivos. Estudos sobre as formas arcaicas dos movimentos sociais nos séculos XIX e XX. Rio de Janeiro: Zahar, 1978].

HOBSBAWM, Eric J. Bandidos. Barcelona: Ariel, 1976. [ed. bras. Bandidos. Rio de Janeiro: Forense Universitária, 1975).

JUAREZ, Francisco N. Bandoleros en la Patagonia. Buenos Aires: Ediciones Z, 2004.

KESSLER, Gabriel \& GAYOL, Sandra (org.). Violencias, delitos y justicias en la Argentina. Buenos Aires: Manantial/UNGS, 2002.

LIZARRAGA, Fernando \& SALGADO, Leonardo. Patagónicos y lombrosianos. Ciencia Hoy, v. 10, n. 59, outubro-novembro, Buenos Aires, 2000. 
LOBOS FRANCO, Edith Inés \& MARTÍNEZ PÉREZ, Teresa del Carmen. El bandidaje: una alteración en el desarrollo histórico de los primeros años de la Frontera. Tesina. Universidad de Chile. Sede Temuco, 1976. Mimeo. MC INTOSH, Mary. La organización del crimen. México: Siglo XXI, 1986.

NARIO, Hugo. Mesias y bandoleros pampeanos. Buenos Aires, Editorial Galerna, 1993.

PALACIO, Juan. La paz del trigo. Cultura legal y sociedad local en el desarrollo agropecuario pampeano 1890-1945. Buenos Aires: Edhasa, 2002.

PALACIOS RÍOS, Germán. Ranquil. La violencia en la expansión de la propiedad agricola. Santiago, 1992.

PAVARINI, Massimo. Control y dominación: teorías criminológicas burguesas y proyecto hegemónico. México: Siglo XXI, 1992.

PINTO RODRÍGUEZ, Jorge. El bandolerismo en la frontera, 1880-1920. In: VILLALOBOS, Sergio \& PINTO, Jorge (org.). Araucania. Temas de historia fonteriza. Temuco: Ediciones Universidad de la Frontera, 1989.

RAFART, Gabriel. Crimen y castigo en el Territorio Nacional del Neuquén, 1884-1920. Estudios Sociales n. 6, UNL, Santa Fé, 1994.

. Tiempo de Violencia en la Patagonia, bandidos, policías y jueces, 1890-1940. Buenos Aires: Editorial Prometeo Libros, 2008.

. Historia y delito en la historiografía argentina reciente. Anuario 2002 de la Universidad de Guadalajara. Guadalajara, 2003.

RAFART, Gabriel et al. Historias de Sangre, Locura y Amor: Neuquén 1900-1950. General Roca: PubliFadecs, 2000.

RAFART, Gabriel; DEBATTISTA, Susana \& BERTELLO, Gabriela. El bandolerismo rural en la última frontera: Neuquén, 1890-1930. Estudios Sociales n. 14, UNL, Santa Fé, 1998.

RUIBAL, Beatriz. Ideología del control social Buenos Aires 1880-1920. Buenos Aires: CEAL, 1993.

SALVATORE, Ricardo \& AGUIRRE, Carlos. The birth of the penitentiary in Latin America: Essays on criminology, prison reform, and social control, 1830-1940. Austin, Texas: University of Texas Press, 1996.

SLATTA, Richard (ed). Bandidos: The varieties of Latin American Banditry. Nova York: Greenwood Press, 1987.

SUÁREZ, Graciela Noelia. La seguridad y el orden: el accionar policial en la región. In: REY, Héctor (coord.). La cordillera rionegrina. Economía, estado y sociedad en la primera mitad del siglo XX. Viedma: Editorial 2010, Bicentenario, 2005.

SUÁREZ, Diego; DEBENER, Marcela \& DEBATTISTA, Susana (org.). Historias secretas del delito y la ley. Neuquén: Educo, 2004

SUÁREZ, Graciela Noelia. La administración de Justicia en el Territorio de Río Negro 1880-1916. Dissertação de mestrado em metodologia da investigação científica, Universidad Nacional de Entre Ríos, 2005.

TELLO, Domingo. Relatos policiales patagónicos del sargento Tello. Viedma: Biblioteca de la Fundación Ameghino, 1981.

TRUJILLO, Juan \& QUINTAR, Juan. Pobres, marginados y peligrosos. Guadalajara: Universidad de Guadalajadra, 2003.

VALENZUELA MÁRQUEZ, Jaime. Bandidaje rural en Chile Central, Curicó, 1850-1900. Santiago de Chile: Dirección de Bibliotecas, Archivos y Museo y Centro de Investigaciones Diego Barros Arana, 1991.

VANDERWOOD, Paul J. Los bandidos de Manuel Payno. Historia Mexicana, v. XLIV, julho-setembro, 173. México: El Colegio de México, 1994. 


\title{
RESUMO
}

$O$ artigo analisa a violência na área rural da Patagônia argentina no final do século XIX e no começo do século XX, ao examinar o mundo do crime numa situação de fronteira, cujo processo de controle e coerção era assumido pelo Estado, sob o olhar atento das classes dominantes argentinas. Bandidos "lendários", venerados por suas açôes criminosas; bandidos "estrangeiros", ou chilenos, além daqueles pertencentes às comunidades indígenas, são investigados a partir da perspectiva de Eric Hobsbawm, o que permite identificar no interior do universo bandoleiro da região patagônia, os chamados "bandidos sociais".

Palavras-chave: Argentina; Patagônia; violência; bandoleirismo; bandidos sociais.

\begin{abstract}
The article analyzes the violence in the rural area of the Argentine Patagonia in the late nineteenth and early twentieth centuries, the crime world in a frontier situation and the process of coercion and control assumed by the state, under the watchful eye of the ruling class in Argentina. Legendary bandits, reverenced by their criminal actions; "foreigners", or Chilean, bandits, besides those belonging to indigenous communities, are investigated from the perspective of Eric Hobsbawm, allowing the identification within the banditry universe of Patagonia, the called "social bandits".
\end{abstract} Keywords: Argentine; Patagonia; violence; banditry; social bandits. 